\title{
High Aluminium Concentration and Soil Acid Saturation Reduce Germination, Emergence and Seedling Establishment of Groundnut
}

\author{
${ }^{1}$ SHEZI, N; *2ADJETEY, JA \\ ${ }^{1}$ Discipline of Crop Science, University of KwaZulu-Natal, Bag X01 Scottsville, Pietermaritzburg \\ ${ }^{* 2}$ Department of Crop Science \& Production, Botswana University of Agriculture \& Natural Resources, Private Bag 0027, Gaborone. \\ *Corresponding Author Email: jaadjetey56@gmail.com
}

\begin{abstract}
Studies on crop responses to soil acidity have largely neglected the germination and seedling establishment stages. The objective of this study was to determine the effect of soil acidity, including aluminium per se and acid saturation, on germination, emergence and establishment of groundnut seeds. Germination was carried out on groundnut cultivars Harts, Jasper and Rambo under $0,50,100$ and $200 \mu \mathrm{M} \mathrm{Al}$ applied as $\mathrm{Al}_{2}\left(\mathrm{SO}_{4}\right)_{3} \cdot 18 \mathrm{H}_{2} \mathrm{O}$ at pH between 4.2 and 4.5. Seedling emergence and establishment were examined in 0,3 and $6 \mathrm{~g}$ of dolomitic lime per $\mathrm{kg}$ of soil, representing control, $50 \%$ lime requirement and $100 \%$ lime requirement, respectively. High $\mathrm{Al}$ concentration of $200 \mu \mathrm{M}$ reduced germination, germination velocity index and seminal root length but had no influence on mean germination time of all groundnut cultivars. There were highly significant differences $(\mathrm{P}<0.001)$ in seedling emergence between non-limed and limed soils. Root length and mass were significantly $(\mathrm{P}<0.05)$ reduced at high soil acidity but the cultivar Rambo was least susceptible. We conclude that the germination, emergence and establishment stages were negatively affected by high $\mathrm{Al}$ levels and acid saturation but the cultivars showed different tolerance levels to high acid saturation, and proper liming can ameliorate the problems associated with these growth stages.
\end{abstract}

DOI: $\underline{\text { https://dx.doi.org/10.4314/jasem.v24i2.11 }}$

Copyright: Copyright $\left({ }^{\circ} 2020\right.$ Shezi and Adjetey. This is an open access article distributed under the Creative Commons Attribution License (CCL), which permits unrestricted use, distribution, and reproduction in any medium, provided the original work is properly cited.

Dates: Received: 16 November 2019; Revised: 11 January 2020; Accepted: 22 February 2020

Key words: acid saturation, aluminium, establishment, peanuts, tolerance

Groundnut is an important leguminous crop grown in sub-Saharan Africa for consumption and has high protein and oil contents. As it grows from germination through to maturity, the influence of soil and other environmental factors have significant effects on its development. Germination and seedling establishment are important in yield determination as a poor seedling stand limits the yield potential of groundnut (Ponkia et al., 1991). Poor seedling establishment is attributed to, among others, poor seed quality (Ellis and Roberts, 1981), soil compaction (Ponkia et al., 1991) and pH (Murata et al., 2011). Studies on crop responses to soil acidity have largely neglected the seedling establishment stage. The effects of high soil acidity operate through the combined influences of high levels of $\mathrm{H}^{+}$and $\mathrm{Al}^{3+}$, also referred to as acid saturation. It is important to understand the effect of acid saturation during the early stages of crop development in order to take necessary measures aimed at improving establishment and, ultimately, yield. Under field conditions seeds and seedlings are confronted by acid saturation rather than soil $\mathrm{pH}$ per se. High acid saturation results in aluminium and manganese toxicity which could affect germination or emergence. In many crops young seedlings are more susceptible to Al toxicity than older plants (Mossor-Pietraszewska, 2001). Exposing seedlings to acid soils could be a quick method of screening for tolerance of groundnuts to soil acidity. Examination of responses of different groundnut cultivars at this early stage could help in a quick decision making on cultivar selection when confronted growing the crop on potentially acidic soils.

The objective of the study was to examine the effect of soil acid saturation, including the role of aluminium, on germination, emergence and seedling establishment of groundnut, and determine whether differences exist between selected cultivars in relation to tolerance to soil acidity.

\section{METHODS AND MATERIALS}

Three groundnut cultivars, Rambo, Jasper and Harts, were treated with Mancozeb ${ }^{\mathrm{TM}}$ (zinc manganese ethylenebisdithiocarbamate) prior to planting.

Germination test: Seeds were germinated using 4 levels of Al namely: 0, 50, 100 and $200 \mu \mathrm{M}$ applied as $\mathrm{Al}_{2}\left(\mathrm{SO}_{4}\right)_{3} .18 \mathrm{H}_{2} \mathrm{O}$ with $\mathrm{pH}$ of 4.3 to 4.5 , depending on amount of $\mathrm{Al}_{2}\left(\mathrm{SO}_{4}\right)_{3} .18 \mathrm{H}_{2} \mathrm{O}$ used. Twenty five seeds of each cultivar were placed on filter papers in petri dishes saturated with the treatment solutions and incubated in a germination chamber at $25^{\circ} \mathrm{C}$ for 5 days. Treatment solutions and filter papers were changed at 24 hourly intervals. The experiment was 
arranged in a completely randomized design, with 5 replications, each replicate comprising four petri dishes. Germination counts were taken daily. Seminal root length was measured after 3 and 5 days, respectively. Final germination was measured as the percentage of seeds producing normal seedlings as defined by ISTA (1995) rules. Germination velocity index was calculated according to Maguire (1962) as:

$\mathrm{GVI}=\mathrm{G}_{1} / \mathrm{N}_{1}+\mathrm{G}_{2} / \mathrm{N}_{2} \ldots+\mathrm{G}_{\mathrm{n}} / \mathrm{N}_{\mathrm{n}}$

Where, GVI = germination velocity index, $\mathrm{G}_{1}, \mathrm{G}_{2} \ldots \mathrm{G}_{\mathrm{n}}$ $=$ number of germinated seeds, and $\mathrm{N}_{1}, \mathrm{~N}_{2}, \mathrm{~N}_{\mathrm{n}}=$ number of days after sowing at the first, second to last counts. Mean time to germination (MGT) was calculated according to the formula of Ellis and Roberts (1981) as: $M G T=\frac{\sum D n}{\sum n}$

Where, $\mathrm{MGT}=$ mean time germination, $\mathrm{n}$ is the number of seeds which were germinated on day $\mathrm{D}$, and $\mathrm{D}$ is number of days counted from the beginning of germination.

Seedling emergence: The Inanda soil form (Soil Classification Working Group, 1991) was used for the experiment. The fertilizer and lime requirements for groundnut were calculated based on results of a soil analysis as: $20 \mathrm{~kg} \mathrm{~N} \mathrm{ha}^{-1}, 20 \mathrm{~kg} \mathrm{P} \mathrm{ha}^{-1}, 85 \mathrm{~kg} \mathrm{~K} \mathrm{ha}^{-1}$ and $9 \mathrm{t} \mathrm{ha}^{-1}$ of dolomitic lime. Treatments consisted of 0,3 and $6 \mathrm{~g}$ of lime per $\mathrm{kg}$ of soil, representing control, $50 \%$ and $100 \%$ of required lime, respectively. Finely ground lime was mixed with soil according to treatment and one part of the mixture was put into germination trays and the rest into pots, for the emergence and establishment studies, respectively. The experiment was a factorial combination of three acid saturation treatments and three groundnut genotypes arranged in a complete randomized block design with four replicates. Germination trays were kept moist by watering lightly twice a day and kept in a controlled temperature growth room $\left(30^{\circ} \mathrm{C}\right.$ day and $15^{\circ} \mathrm{C}$ night). Twenty eight seeds per cultivar were sowed at a depth of $2.5 \mathrm{~mm}$ in each $15 \mathrm{~cm}$ deep tray and allowed to grow for 10 days. Daily counts of emerged seeds were recorded. Emergence was defined as hypocotyl protrusion from the soil. At 10 days after sowing (DAS) seedlings were harvested and final emergence was determined as the percentage of seeds producing normal seedlings as defined by ISTA (1995) rules. Seedling root and shoot lengths, shoot and root dry masses were measured.

Mean emergence time was calculated according to the formula by Bewley and Black (1994) as: MET $=\frac{\sum \boldsymbol{f x}}{\boldsymbol{f}}$
Where $\mathrm{MET}=$ mean emergence time, $\mathrm{f}=$ number of newly germinating seeds at a given time (day), and $\mathrm{x}$ $=$ number of days from date of sowing.

Seedling establishment: Treatments for assessing effect of soil acidity on seedling establishment were the same as for the emergence experiment except that they were grown in pots. The seedlings were allowed to grow for 21 days, harvested and root and shoot lengths measured. Leaf area was determined using a leaf area meter (LI-3000C, LI-COR ${ }^{\circledR}$ ). The roots and shoots were oven dried for $48 \mathrm{~h}$ at $65^{\circ} \mathrm{C}$ to determine dry weight.

Data analysis: Data were subjected to analysis of variance (ANOVA) using the GenStat ${ }^{\mathbb{R}}$ Version 12 (VSN International Ltd, UK). Least significant difference $(\mathrm{P}>0.05)$ was used to separate treatment means.

\section{RESULTS AND DISCUSSION}

Germination: Aluminium concentration significantly $(\mathrm{P}<0.001)$ reduced mean groundnut germination from $91.7-100 \%$ at $0-100 \mu \mathrm{M}$ to $88.3 \%$ at $200 \mu \mathrm{M}$ (Table 1). Similarly, germination velocity index was reduced $(\mathrm{P}<0.05)$ to 1.63 by $200 \mu \mathrm{M} \mathrm{Al}$ compared to about 2.0 for $0-100 \mu \mathrm{M}$. Mean time to germination (MGT) was not different $(\mathrm{P}>0.05)$ amongst the cultivars, $\mathrm{Al}$ treatments or their interaction. High $\mathrm{Al}$ concentrations between 100 and $200 \mu \mathrm{M}$, reduced $(\mathrm{P}<0.001)$ seminal root length in all cultivars (Fig 1) and the difference between 0 and $200 \mu \mathrm{M}$ were especially high at 5 DAS. At 5 DAS the seminal root length of control treatments was as least double that of the $200 \mu \mathrm{M} \mathrm{Al} \mathrm{level} \mathrm{for}$ Harts and Jasper, while the difference for Rambo was less than this value. In all treatments root length of Rambo was slightly lower than those of Harts and Jasper.

Seedling emergence: Seedlings emergence commenced at $5 \mathrm{DAS}$, and all cultivars reached a peak on day 8 (Fig 2). High soil acid saturation reduced $(\mathrm{P}<0.001)$ percentage emergence from $98.9 \%$ at full amelioration (20\% AS) to $88.5 \%$ without amelioration $(80 \%$ AS). Mean emergence time was not affected $(\mathrm{P}>0.05)$ by liming rate/acid saturation and differences among genotypes were small (Table 2). Both root lengths and masses of seedlings were suppressed $(\mathrm{p}<$ 0.05 ) at high soil acid saturation across cultivars. Shoot dry mass was not altered by varying soil acidity but small differences were observed amongst the cultivars. Also, Ca deficiency symptom of leaf curling was observed in Hart at $80 \%$ acid saturation during the study. 
Table 1: Effect of differential Al concentrations on seed germination, germination velocity index (GVI) and mean time to germination (MGT) of three groundnut cultivars.

\begin{tabular}{|c|c|c|c|c|}
\hline Al concentration $(\mu \mathrm{M})$ & Cultivar & Final germination $\%$ & GVI & MGT (days) \\
\hline \multirow[t]{3}{*}{0} & Hart & 100.0 & 2.07 & 2.45 \\
\hline & Jasper & 90.0 & 2.00 & 2.52 \\
\hline & Rambo & 95.0 & 2.04 & 2.50 \\
\hline Means & & 95.0 ab & $2.04 \mathrm{a}$ & $2.49 \mathrm{a}$ \\
\hline \multirow[t]{3}{*}{50} & Hart & 100.0 & 2.24 & 2.25 \\
\hline & Jasper & 100.0 & 1.99 & 2.70 \\
\hline & Rambo & 100.0 & 1.90 & 2.36 \\
\hline Mean & & 100.0 a & $2.04 \mathrm{a}$ & $2.44 \mathrm{a}$ \\
\hline \multirow[t]{3}{*}{100} & Hart & 95.0 & 2.01 & 2.38 \\
\hline & Jasper & 95.0 & 1.94 & 2.45 \\
\hline & Rambo & 85.0 & 1.96 & 2.63 \\
\hline Mean & & $91.7 \mathrm{~b}$ & $1.97 \mathrm{a}$ & $2.48 \mathrm{a}$ \\
\hline \multirow{3}{*}{200} & Hart & 90.0 & 1.75 & 2.53 \\
\hline & Jasper & 85.0 & 1.53 & 2.76 \\
\hline & Rambo & 90.0 & 1.62 & 2.85 \\
\hline Mean & & $88.3 \mathrm{~b}$ & $1.63 \mathrm{~b}$ & $2.71 \mathrm{a}$ \\
\hline P (Al conc.) & & 0.02 & 0.01 & 0.09 \\
\hline $\operatorname{LSD} \mathbf{A l}_{(\mathbf{P}=0.05)}$ & & 7.38 & 0.27 & NS \\
\hline CV & & 9.50 & 16.80 & 11.20 \\
\hline
\end{tabular}

$G V I=$ Germination velocity index; $M G T=$ Mean time to germination

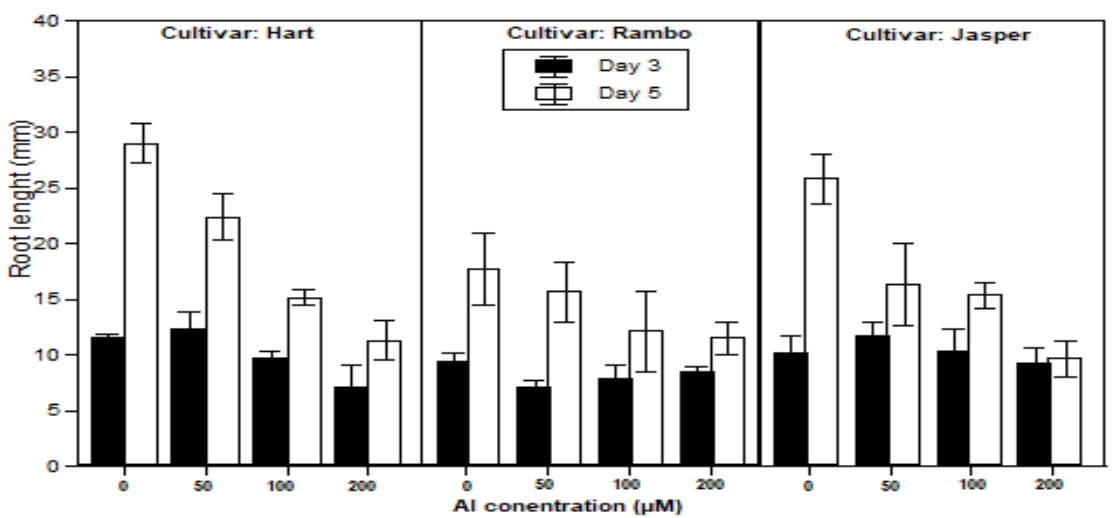

Fig 1. Effect of Al concentration on seminal root length of three groundnuts cultivars measured at 3 and 5 days after incubation.

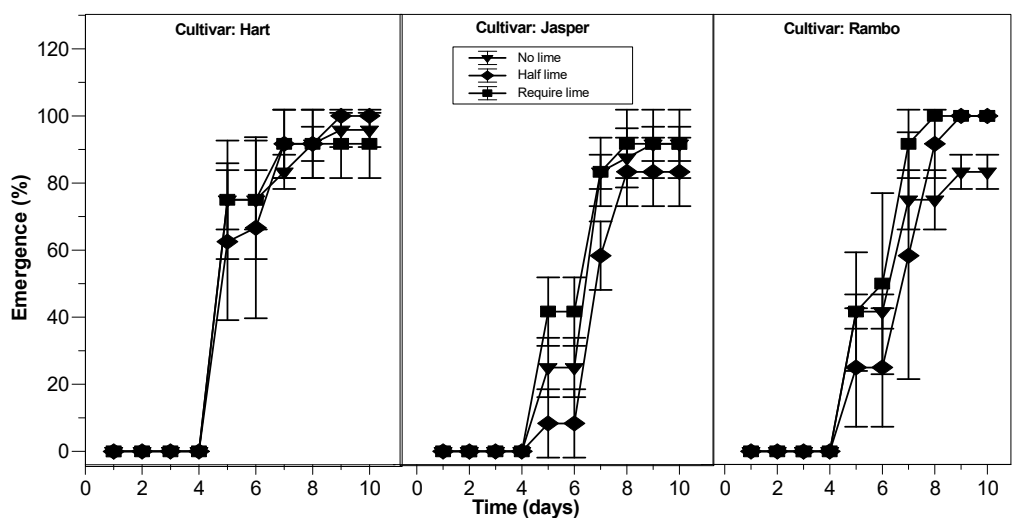

Fig 2. Effect of soil acidity on emergence of three groundnut cultivars Harts, Jasper and Rambo

Establishment: During the establishment phase, high soil acidity significantly $(\mathrm{P}<0.05)$ reduced shoot length and dry mass (Table 3) and Harts and Jasper had higher shoot lengths compared to Rambo. Differences in leaf area were not significant $(\mathrm{P}>0.05)$ although the lowest values were associated with high soil saturation (Table 3). Root dry mass was increased significantly by lime application, and also, differed amongst the cultivars. At $80 \%$ acid saturation, Rambo had the highest root dry mass while Harts had the 
lowest (Table 3). Acidity apparently did not affect root length, which in this case was a measure of depth of penetration rather than total root development (Table 3 and Plate 1). In addition to inhibition of root growth, high $\mathrm{Al}$ concentration of $200 \mu \mathrm{M}$ resulted in roots that were particularly thick and brownish (Plate $1)$.

In this study, groundnut germination was sensitive to high Al concentrations with both germination percentage and speed decreasing with increasing $\mathrm{Al}$ concentration. Thus, in contrast to the report by Murata et al. (2011) in which acidity measured by $\mathrm{pH}$ did not affect germination, acidity due to high acid saturation $(\mathrm{Al}$ and $\mathrm{pH})$ and $\mathrm{Al}$ per se had a negative influence on both germination and emergence rather than the latter alone. In field conditions, prolonged time to germination exposes seeds to deterioration, hence high soil acidity that delays germination as in this study, with reduced GVI, can result in poor seedling emergence in field conditions. Aluminium concentration between 0 and $50 \mu \mathrm{M}$ had little effect on germination in all cultivars compared to 100 and 200 $\mu \mathrm{M}$, a result similar to those Rout et al. (2001) and Jamal et al. (2006) which suggested that low concentrations of $\mathrm{Al}$ less than $20 \mathrm{ppm}$ could enhance seed germination while the effects were adverse at concentrations higher than $20 \mathrm{ppm}$. Our study suggests that Al toxicity not only reduces seed germination, but also limits root expansion after radicle protrusion. Thus the negative effect of high $\mathrm{Al}$ manifests itself quickly. Furthermore, roots exposed to Al toxicity became stubby and brittle while root tips and lateral roots become thick and turn brown, and this has negative consequences for water and nutrient absorption and crop growth.

Table 2. Effect of soil acid saturation on emergence and seedling growth of three groundnut cultivars grown with no lime (80 \% AS), $50 \%$ required lime $(40 \% \mathrm{AS})$ and $100 \%$ required lime $(20 \% \mathrm{AS})$.

\begin{tabular}{|c|c|c|c|c|c|c|}
\hline $\begin{array}{l}\text { Lime } \\
\text { application (g } \\
\mathrm{kg}^{-1} \text { soil) }\end{array}$ & Cultivar & $\begin{array}{l}\text { MET } \\
\text { (days) }\end{array}$ & $\begin{array}{l}\text { Shoot } \\
\text { height } \\
(\mathrm{mm})\end{array}$ & $\begin{array}{l}\text { Root } \\
\text { lenght } \\
(\mathrm{mm})\end{array}$ & $\begin{array}{l}\text { Shoot } \\
\text { mass/plant } \\
\text { (g) }\end{array}$ & $\begin{array}{l}\text { Root } \\
\text { mass/plant } \\
\text { (g) }\end{array}$ \\
\hline \multirow{3}{*}{$\begin{array}{l}\text { No lime } \\
(80 \% \text { AS) }\end{array}$} & Hart & 5.10 & 64.2 & 104.0 & 0.26 & 0.11 \\
\hline & Jasper & 5.84 & 66.7 & 62.7 & 0.18 & 0.08 \\
\hline & Rambo & 5.62 & 63.8 & 52.3 & 0.17 & 0.09 \\
\hline Mean & & $5.52 \mathrm{a}$ & $64.9 \mathrm{~b}$ & 73.0 b & $0.21 \mathrm{a}$ & 0.09 b \\
\hline \multirow{3}{*}{$\begin{array}{l}3 \\
(40 \% \mathrm{AS})\end{array}$} & Hart & 5.39 & 70.2 & 128.2 & 0.30 & 0.14 \\
\hline & Jasper & 6.01 & 73.2 & 113.8 & 0.16 & 0.11 \\
\hline & Rambo & 5.55 & 66.7 & 87.4 & 0.19 & 0.10 \\
\hline Mean & & $5.65 \mathrm{a}$ & $70.0 \mathrm{ab}$ & $109.8 \mathrm{a}$ & $0.21 \mathrm{a}$ & $0.12 \mathrm{a}$ \\
\hline \multirow{3}{*}{$\begin{array}{l}6 \\
(20 \% \text { AS })\end{array}$} & Hart & 5.47 & 80.1 & 130.6 & 0.19 & 0.15 \\
\hline & Jasper & 5.69 & 75.0 & 122.2 & 0.23 & 0.10 \\
\hline & Rambo & 5.78 & 70.7 & 92.9 & 0.21 & 0.12 \\
\hline Mean & & $5.65 \mathrm{a}$ & $75.3 \mathrm{a}$ & $115.2 \mathrm{a}$ & $0.21 \mathrm{a}$ & 0.12 a \\
\hline $\mathbf{P}(\mathbf{A l})$ & & 0.37 & 0.02 & $<0.001$ & 0.880 & 0.032 \\
\hline P (inter) & & 0.14 & 0.77 & 0.10 & 0.007 & 0.936 \\
\hline $\operatorname{LSD}_{(\mathrm{P}=0.05)}{ }^{1}$ & & 0.21 & 7.03 & 10.07 & 0.038 & 0.025 \\
\hline $\operatorname{LSD}_{(\mathrm{P}=0.05)}{ }^{2}$ & & 0.37 & 12.17 & 17.44 & 0.066 & 0.043 \\
\hline CV\% & & & 10.00 & 10.10 & 18.10 & 22.30 \\
\hline
\end{tabular}
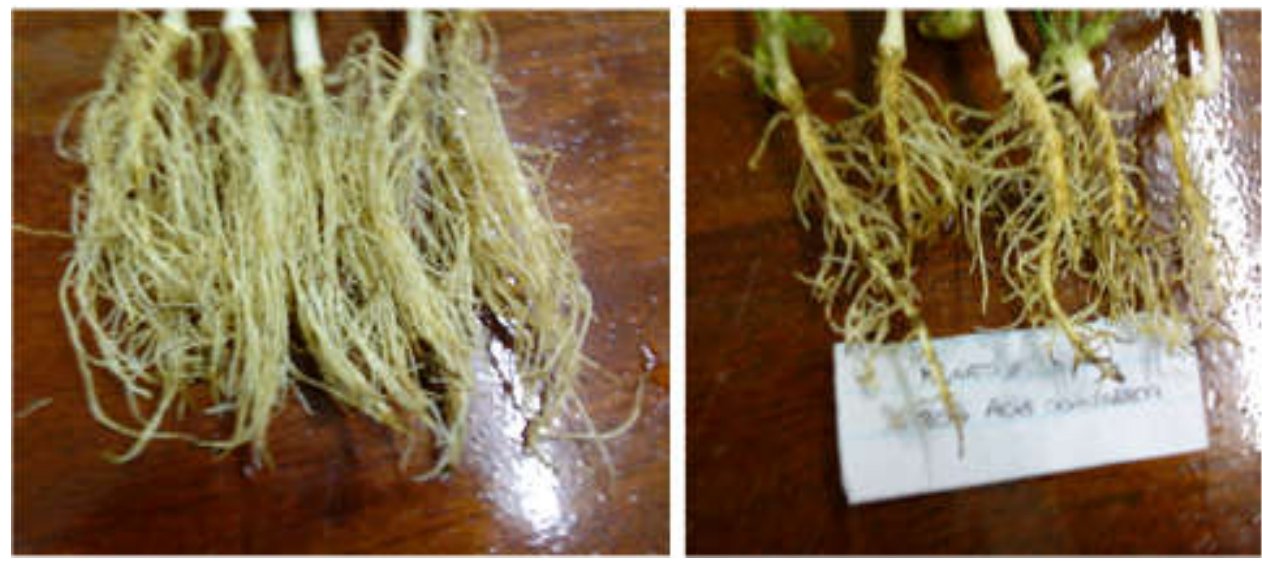

Plate 1. Effect of lime on root development in groundnut seedlings: left, roots of seedlings grown at $20 \%$ acid saturation and right roots of seedlings with no lime application ( $80 \%$ acid saturation) 
Table 3: Effect of differential soil acidity on seedling establishment measured at 21 days after planting

\begin{tabular}{|c|c|c|c|c|c|c|}
\hline $\begin{array}{l}\text { Lime application } \\
\left(\mathrm{g} \mathrm{kg}^{-1} \text { soil) }\right.\end{array}$ & Cultivars & $\begin{array}{l}\text { Shoot length } \\
(\mathrm{mm})\end{array}$ & $\begin{array}{l}\text { Root length } \\
(\mathrm{mm})\end{array}$ & $\begin{array}{l}\text { Shoot dry } \\
\text { mass (g) }\end{array}$ & $\begin{array}{l}\text { Root dry } \\
\text { mass (g) }\end{array}$ & $\begin{array}{l}\text { Leaf area } \\
\left(\mathrm{cm}^{2}\right)\end{array}$ \\
\hline \multirow{3}{*}{$\begin{array}{l}\text { No lime } \\
(80 \% \text { AS) }\end{array}$} & Harts & 136.7 & 210.0 & 1.31 & 0.23 & 218.9 \\
\hline & Jasper & 153.3 & 246.0 & 1.13 & 0.32 & 190.4 \\
\hline & Rambo & 115.0 & 246.7 & 1.09 & 0.35 & 214.5 \\
\hline Mean & & $135.0 \mathrm{~b}$ & 234.2 a & $1.18 \mathrm{~b}$ & $0.29 \mathrm{~b}$ & 207.9 a \\
\hline \multirow{3}{*}{$\begin{array}{l}3 \\
(40 \% \mathrm{AS})\end{array}$} & Harts & 165.0 & 201.7 & 1.45 & 0.29 & 243.8 \\
\hline & Jasper & 135.0 & 263.3 & 1.25 & 0.37 & 203.7 \\
\hline & Rambo & 121.7 & 220.0 & 1.39 & 0.44 & 247.9 \\
\hline Mean & & $140.6 \mathrm{ab}$ & $228.3 \mathrm{a}$ & $1.36 \mathrm{a}$ & $0.37 a$ & $231.8 \mathrm{a}$ \\
\hline \multirow{3}{*}{$\begin{array}{l}6 \\
(20 \% \mathrm{AS})\end{array}$} & Harts & 158.3 & 249.0 & 1.55 & 0.32 & 256.6 \\
\hline & Jasper & 161.7 & 212.7 & 1.39 & 0.28 & 259.2 \\
\hline & Rambo & 123.3 & 255.7 & 1.20 & 0.44 & 209.5 \\
\hline Mean & & $147.8 \mathrm{a}$ & $239.1 \mathrm{a}$ & $1.38 \mathrm{a}$ & $0.35 \mathrm{a}$ & 241.8 a \\
\hline$P($ treatment $)$ & & 0.049 & 0.06 & 0.017 & 0.060 & 0.221 \\
\hline P (inter.) & & 0.151 & 13.50 & 0.61 & 0.15 & 0.38 \\
\hline P (cultivars) & & 0.001 & 0.06 & 0.06 & 0.001 & 0.31 \\
\hline $\operatorname{LSD}_{(\mathrm{P}=0.05)}{ }^{1}$ & & 10.030 & 31.51 & 0.18 & 0.048 & 40.49 \\
\hline $\operatorname{LSD}_{(\mathrm{P}=0.05)^{2}}$ & & 17.370 & $\mathbf{5 4 . 5 7}$ & 0.32 & 0.084 & 70.13 \\
\hline CV\% & & 14.400 & 0.098 & 14.10 & 14.40 & 17.80 \\
\hline
\end{tabular}

The emergence study showed that like MGT, MET was not influenced by high soil acidity but the decline in seedling emergence and root mass observed suggests that this stage is vulnerable and hence a possible cause for ultimate yield reduction with high acid saturation. Indeed, poor seedling establishment results in reduced yields in many crops (Fageria and Baligar, 1997). Inhibition of root expansion is a major symptom of Al toxicity as observed in this study. Kochain (2004) and Ma (2007) suggested that $\mathrm{Al}$ inhibited root elongation within hours of exposure and thus affected nutrient and water uptake, resulting in poor growth. The reduction in root mass in this study was the result of a reduction in lateral roots at high acid saturation. Lateral roots are involved in nutrient and water uptake and in legumes they are also required for infection by rhizobia for successful nodulation (Brandy et al, 1993). The roots affected by Al toxicity/high acid saturation are inefficient in absorbing water and nutrients, thus affecting shoot growth (Jamal et al., 2006). In the establishment study, root length was a measure of depth of penetration rather than root proliferation thus the lengths measured were nearly similar. However, lateral root development was very severely inhibited resulting in the large differences in root dry mass for the different acid treatments, an observation consistent with the report of Kochain (2004) and Ma (2007). This may explain the reduced shoot growth (shoot length) observed in the zero lime treatment.

As the degree of root inhibition by high acid saturation was smallest in Rambo, it is considered the most tolerant to acid saturation among the cultivars used. Thus in acid soils in field conditions, Rambo is less likely to suffer to the same degree in terms of the degree of root inhibition and the consequences arising from that e.g. nutrient and water uptake. This observation suggests that differences exist amongst groundnut genotypes in response to high acid saturation and these may be exploited for improved productivity with limited liming.

Conclusion: Groundnut seedlings are susceptible to high Al levels and acid saturation which inhibit germination, emergence and establishment. Rambo was more tolerant to high $\mathrm{Al}$ levels and acid saturation than Harts and Jasper suggesting genotypic variations in the response to acid saturation. High Al saturation can therefore affect crop yield due to its negative influence on the early phase of groundnut growth. Subjecting groundnuts to high acidity during this period can be used as a quick screening tool for tolerance to acidity.

\section{REFERENCES}

Bewley, JD; Black, M (1994). Seeds: Physiology of development and germination, $2^{\text {nd }}$ Edition, Plenum, New York. 445 pp.

Brandy, DJ; Edwards, DG; Asher, CJ; Blamey, FPC (1993). Calcium amelioration of aluminium toxicity effect on root hair development in soybean (Glycine max L.). New Phytologist 123 (3): 531-538.

Ellis, RA; Roberts, EH (1981). The quantification of ageing and survival in orthodox seeds. Seed Science and Technology 9: 373 - 409.

Fageria, NK; Baligar, VC (1997). Integrated plant nutrient management for sustainable crop production. International Journal of Tropical Agriculture 15: 7-18. 
ISTA. 1995. Handbook of vigour test methods. $3^{\text {rd }}$ Edition. ISTA Zurich.

Jamal, SN; Iqbal, MZ; Ather, M (2006). Phytotoxic effect of aluminium and chromium on the germination and early growth of wheat (Triticum aestivum) varieties, Anmol and Kiran. Journal of Environmental Science 3: 411- 4116.

Kochain, LV (2004). The physiology, genetics and molecular biology of plant aluminium resistance and toxicity. Journal of Plant and Soil 274: 175195.

Ma, JF (2007). Syndrome of aluminium toxicity and diversity of aluminium resistance in higher plants. International. Review of Cytology 264: 225- 252

Maguire, JD (1962). Speed of germination aid in selection and evaluation for seedling emergence and vigour. Crop Science 2: 176 - 177.

Mossor-Pietraszewska, T (2001). Effect of aluminium on plant growth and metabolism. Acta Biologica Polonica 48: 673-686.
Murata, M; Hammes, PS; Zharare, GE (2011). The effect of solution $\mathrm{pH}$ and calcium concentration on germination and early growth of groundnut. Journal of Plant Nutrition 26: (6) 1274-1262.

Ponkia, HP; Patel, CL; Polara, KB; Polara, JV (1991). Water absorption and seed water diffusivity of germinating seed of groundnut varieties at different levels of soil compaction. Legume Research. 14: 111-119

Rout, GR; Samantary, S; Das, P (2001). Aluminium toxicity in plants: a review. Journal of Agronomy 21: 3- 21 .

Soil Classification Working Group (1991). Soil classification: a taxonomic system for South Africa. Department of Agricultural Development. Pretoria, South Africa. 